\title{
PENGEMBANGAN MORAL ANAK DI LINGKUNGAN LOKALISASI PASAR KEMBANG TK PKK SOSROWIJAYAN YOGYAKARTA
}

\author{
Muhammad Syafe'i dan Rukiyati \\ Program Pascasarjana Universitas Negeri Yogyakarta \\ p_oel@yahoo.com, dan rukiyati@uny.ac.id
}

\begin{abstract}
Abstrak: Penelitian ini bertujuan untuk mengungkapkan pengembangan moral anak TK PKK Sosrowijayan Yogyakarta dan mengungkapkan perkembangan moral anak TK PKK Sosrowijayan Yogyakarta. Pendekatan yang digunakan dalam penelitian ini adalah pendekatan kualitatif. Subjek penelitian ini terdiri atas kepala sekolah, guru, dan anak didik TK PKK Sosrowijayan Yogyakarta. Data penelitian dikumpulkan melalui wawancara, observasi, dan analisis dokumen. Data penelitian dianalisis menggunakan teknik analisis kualitatif secara interaktif. Hasil penelitian menunjukkan bahwa pengembangan moral anak TK PKK Sosrowijayan mencakup aspek materi, pendidik, metode dan evaluasi. Materi yang dikembangkan di TK Sosrowijayan mengacu pada Permendiknas No. 58 Tahun 2009 tentang Standar Pendidikan Anak Usia Dini. Pendidik sudah dapat menjadi teladan bagi anak. Metode pengembangan moral menggunakan metode: pembiasaan, bercerita, keteladanan, dan bernyanyi. Evaluasi yang digunakan evaluasi proses menggunakan teknik observasi tanpa lembar observasi dan hanya mengandalkan ingatan guru.
\end{abstract}

Kata Kunci: pengembangan moral, lokalisasi, taman kanak-kanak.

\section{THE MORAL DEVELOPMENT OF CHILDREN IN PASAR KEMBANG PROSTITUTION OF PKK KINDERGARTEN SOSROWIJAYAN YOGYAKARTA}

Abstract: This study aims to: (1) reveals the moral development of children in kindergartens PKK Sosrowijayan Yogyakarta, and (2) reveals the moral development of children in kindergartens PKK Sosrowijayan Yogyakarta. The approach used in this study is qualitative. Subjects of this study consisted of principals, teachers, and students PKK kindergarten, Sosrowijayan, Yogyakarta, Indonesia. The research data was collected through interviews, observation and document analysis. Data were analyzed using qualitative analysis techniques interactively: data collection, data reduction, data presentation, and conclusion. The results showed that the moral development of TK PKK Sosrowijayan covers the material aspects, educators, methods and evaluation. The material was developed in kindergarten Sosrowijayan refers Permendiknas No 58 of 2009. Educators have can be a role model for students. Moral development method using the method: habituation, storytelling, modeling and singing. Evaluations are used in the evaluation process using observation without observation sheets teachers just rely on memory. Moral development of children in accordance with the stages of development of children aged 5-6 years.

Keywords: moral development, prostitution, kindergarten

\section{PENDAHULUAN}

Masa anak-anak merupakan masa yang sangat peka. Usia ini juga anak-anak akan cepat sekali menyerap apa yang ia lihat. Anak diibaratkan spons yang akan menyerap segala macam air yang ada. Pada tahap ini anak belum mempunyai filter atau penyaring hal-hal yang baik dan hal yang buruk. Pendidik sebagai orang yang paham dengan karakteristik anak harus bisa memberikan filter bagi anak, sehingga ketika anak berinteraksi langsung dengan lingkungannya, ia bisa membentengi dirinya sendiri.
Maimunah (2012: 12) mengemukakan pendidikan anak usia dini (PAUD) adalah jenjang pendidikan sebelum jenjang pendidikan dasar yang merupakan suatu upaya pembinaan yang ditujukan bagi anak sejak lahir sampai dengan usia enam tahun yang dilakukan dengan memberi rangsangan pendidikan untuk membantu pertumbuhan dan perkembangan jasmani serta rohani agar anak memiliki kesiapan dalam memasuki pendidikan lanjut, yang diselenggarakan pada jalur formal, nonformal, dan informal.

NAEYC mengemukakan bahwa: 
Early childhood education involves any group program children from birth to 8 years of age that is designed to promote children's intellectual, social, emotional, language and physical development (Kostelnik, 1999: 2).

Penjelasan dari pernyataan tersebut adalah bahwa pendidikan anak usia dini adalah pendidikan yang dimulai dari kelompok usia 0-8 tahun, yang ditujukan untuk mengembangkan aspek perkembangan intelektual, sosial, emosional, bahasa, dan perkembangan fisik anak.

Perkembangan anak usia dini dalam hal ini sangat pesat. Oleh karena itu, sebagai orang yang memahami tentang perkembangan harus membantu aspek perkembangan anak agar tumbuh dengan maksimal. Masa peka pada masing-masing anak berbeda, seiring dengan laju pertumbuhan dan perkembangan anak secara individual. Salah satu aspek perkembagan anak usia dini adalah nilai moral. Pengembangan moral dan nilai-nilai agama sejak kecil yang dimulai pada anak usia dini pada dasarnya oleh sebuah keprihatinan atas realitas anak didik bahkan hasil pendidikan di Indonesia yang belum sepenuhnya mencerminkan kepribadian yang bermoral, yakni santun dalam bersikap dan berperilaku. Hal ini menunjukkan bahwa ada sesuatu yang perlu diperbaiki dalam sistem pendidikan kita, khususnya pada jenjang pendidikan anak usia dini. Oleh karena itu, sebagai upaya awal perbaikan terhadap sistem pendidikan di Indonesia sangat diperlukan adanya pengembangan moral dan nilai-nilai agama sejak dini sebagai upaya pengokohan mentalspiritual anak

Moralitas adalah kualitas dalam perbuatan manusia yang dengan itu ia berkata bahwa perbuatan itu benar atau salah, baik atau buruk. Moralitas mencangkup pengertian tentang baik buruknya perbuatan manusia. Moralitas dapat bersifat objektif atau subjektif. Moralitas yang bersifat objektif memandang perbuatan semata-mata sebagai suatu perbuatan yang telah dikerjakan. Moralitas subjektif adalah moralitas yang memandang perbuatan sebagai perbuatan yang dipengaruhi pengertian dan persetujuan si pelaku sebagai individu (Poespoprodjo, 1998: 102).

Gibbs dkk mengemukakan perkembangan moral adalah perubahan penalaran, perasaan, dan perilaku tentang standar mengenai benar dan salah.
Perkembangan moral memiliki dimensi intrapersonal, yang mengatur aktivitas seseorang ketika ia tidak terlibat dalam interaksi sosial dan dimensi interpersonal yang mengatur interaksi sosial dan penyelesaian konflik (Santrock, 2007: 117).

Kohlberg mengemukakan bahwa moralitas lebih dari segi formalnya sebuah pertimbangan moral atau suatu titik pandangan moral, ketimbang dari segi isinya. Impersonalitas, idealitas, universalitas, dan aprioritas, merupakan sejumlah ciri formal dari suatu pertimbangan moral. Kohlberg juga mengemukakan definisi formal tentang moral yang hanya berlaku apabila diakui bahwa terdapat tingkat-tingkat perkembangan dari percakapan atau pertimbangan moral yang semakin mendekati bentuk-bentuk formal ideal moralitas (Kohlberg, 1995: 163).

Kohlberg dalam hasil penelitiannya menggunakan ceritera-ceritera hipotetik yang mengandung dilema-dilema moral. Kohlberg menyimpulkan bahwa ada tiga tingkatan utama tentang moral reasoning yang tingkatantingkatan itu terdiri atas dua tahap sebagai berikut (Santrock, 2010: 368).

Level I : Preconventional Morality

Stage1. Punishmen and Obidience orientation.

Stage 2. Individualism, Instrumental purpose, and exchange.

Level II : Conventional Morality

Stage 3. Mutual interpersonal expectations, relationship, and interpersonal conformity.

Stage 4. Social system and conscience (law and order).

Level III. Postconventional Morality or Principled

Stage 5. Social contract or utility and individual right.

Stage 6. Universal ethical principles.

Pada tingkatan prakonvensional, anak akan peka terhadap peraturan-peraturan, anak belum menunjukkan internalisasi nilai-nilai moral karena pada tahap ini merupakan tahap dasar bagi anak. Pada level 1 ada dua tahap yakni hukuman dan kepatuhan, pada tahap ini suatu tindakan dinilai benar atau salah tergantung dari hukuman yang berkaitan dengan hal yang dilakukan. Pada level 2 merupakan tingkatan konvensional terdiri atas dua tahap yakni orientasi konformitas interpersonal dan tahap orientasi hukum dan 
aturan. Pada tahap ini moral anak masih mmengacu pada peristiwa-peristiwa eksternal fisik, suatu tindakan dikatakan benar atau salah bila berkaitan dengan kejadian eksternal yang memuaskan kebutuhan dirinya atau kebutuhan seseorang yang dekat dengan dirinya.

Level 3 merupakan tingkatan pasca konvensional. Pada tahap ini sudah ada usaha yang jelas dalam diri anak untuk menentukan nilai dan prinsip yang valid yang dapat dilakasanakan. Pada tahap ini sesuatu dianggap benar cenderung dimengerti dari hak-hak individual yang umum sebagai patokan yang dibuat masyarakat.

Pendidikan Moral Anak Usia Dini terdiri atas beberapa aspek, yaitu:

\section{Materi}

Nurul Zuriah (2007: 27-28) mengemukakan secara garis besar ruang lingkup materi pendidikan moral atau budi pekerti dapat dikelompokkan dalam tiga nilai aklhak yaitu sebagai berikut: akhlak terhadap Tuhan Yang Maha Esa, akhlak terhadap sesama manusia, dan akhlak terhadap lingkungan.

\section{Pendidik}

Pendidik atau guru anak usia dini garus memiliki kepribadian yang baik, dan dapat menjadi teladan untuk anak-anak. Abd. Rachman Shaleh dan Soependri Suriadinata ada beberapa ciri kepribadian yang harus dimiliki oleh guru/pendidik antara lain (Fathul Mu'in, 2011: 350).

1. Guru harus bertakwa kepada Tuhan Yang Maha Esa dengan segala sifat, sikap, dan amaliahnya yang mencerminkan ketakwaannya tersebut.

2. Guru harus suka bergaul, khususnya bergaul dengan anak-anak.

3. Guru adalah orang yang penuh minat, penuh perhatian, mencintai profesinya dan pekerjaannya, dan berusaha untuk mengembangkan dan meningkatkan profesinya itu agar kemampuan mengajarnya lebih baik.

4. Guru adalah orang yang suka belajar terus menerus, meskipun ia adalah pendidik yang identik menularkan pengetahuan dan menyebarkan wawasan, namun juga harus menjadi orang yang terdidik yang selalu mempelajari hal-hal baru.
Metode

Metode pembelajaran merupakan suatu cara atau sistem yang digunakan dalam pembelajaran yang bertujuan agar anak didik dapat mengetahui, memahami, mempergunakan, dan menguasai bahan pelajaran tertentu (Ahmad dan Lilik, 2009: 29). Dalam pelaksanaan penanaman moral pada anak usia dini, beberapa metode ini dapat menjadi referensi guru yaitu:

1. Metode bercerita

Metode bercerita dapat menjadi metode untuk mengembangkan moral anak karena dalam cerita dapat menanamkan nilai moral, nilai agama, nilai sosial, nilai budaya dan sebagainya. Dalam bercerita guru juga dapat menggunakan alat peraga untuk menambah daya tarik anak dan mengatasi keterbatasan anak dalam berfikir abstrak.

2. Metode Bernyanyi

Metode bernyanyi adalah suatu pembelajaran secara nyata yang mampu membuat anak senang dan bergembira, karena lewat bernyanyi anak tidak sadar sedang belajar. Dalam metode bernyanyi dapat menyisipkan pesan-pesan moral yang dikenalkan kepada anak.

3. Metode Pembiasaan

Metode pembiasaan merupakan sebuah cara yang dapat dilakukan dalam mengembangkan moral dengan cara membiasakan anak melakukan hal-hal kecil sesuai dengan nilai moral. Metode pembiasaan sering disebut proses membuat sesuatu yang tidak biasa menjadi kebiasaan. Hal ini sangat bisa diterapkan kepada anak, jadi anak akan terbiasa berbuat yang baik dan hal itu diyakini akan menjadi tingkah laku yang menetap.

4. Metode Keteladanan

Metode keteladanan adalah cara belajar anak dengan meniru perilaku sikap atau perilaku seseorang. Sesuai dengan karakteristik anak yang suka meniru maka hal ini dapat di lakukan untuk mengembangkan moral anak.

Sejalan dengan pendapat tersebut, Kirschenbaum secara lebih terperinci mengemukakan pengembangan moral dapat dilakukan dengan metode sebagai berikut. (Zuchdi, 2008: 46-50).

1. Inkulkasi nilai 
Inkulkasi atau penanaman nilai memiliki ciri-ciri: 1) Mengkomunikasikan kepercayaan disertai alasan yang mendasarinya; 2) Memperlakukan orang secara adil; 3) Menghargai pandangan orang lain; 4) Mengemukakan keragu-raguan atau perasaan tidak percaya disertai dengan alas an dan dengan rasa hormat; 5) tidak sepenuhnya mengontrol lingkungan untuk meningkatkan kemungkinan penyampaian nilai-nilai yang dikehendaki dan mencegah kemungkinan penyampaian nilai-nilai yang tidak dikehendaki; 6) Menciptakan pengalaman sosial dan emosional mengenai nilai-nilai yang dikehendaki secara tidak ekstrem; 7) Membuat aturan memberikan, penghargaan, dan memberikan konsekuensi disertai alasan. 8) Tetap membuka komunikasi dengan pihak yang tidak setuju; 9) Memberikan kebebasan bagi adanya perilaku yang berbeda-beda apabila sampai tingkat yang tidak diterima, diarahkan untuk memberikan kemungkinan berubah.

\section{Keteladanan Nilai}

Metode keteladanan nilai ada dua syarat yang harus dipenuhi yakni: pertama, guru atau orang tua harus berperan sebagai model yang baik bagi murid-murid. Kedua, anak-anak harus meneladani orang yang terkenal yang berakhlak mulia, misalnya Nabi Muhammad saw. Guru dan orang tua dalam menggunakan metode keteladanan nilai harus memiliki keterampilan asertif, yakni ketrampilan mengemukaan pendapat secara terbuka dengan cara tidak melukai perasaan orang lain.

\section{Fasilitasi Nilai}

Fasilitasi merupakan cara untuk memberikan fasilitas dengan tujuan melatih subjek mengatasi masalah-masalah yang timbul pada anak. Kirschenbaum mengemukakan bahwa dalam pelaksanakan metode fasilitasi dapat membawa dampak positif pada perkembangan kepribadian sebagai berikut (Zuchdi, 2008: 48-49): a) Kegiatan fasilitasi secara signifikan dapat meningkatkan hubungan pendidik dan subjek didik. b) Kegiatan fasilitasi menolong subjek didik memperjelas pemahaman. Kegiatan tersebut memberikan kesempatan kepada subjek didik untuk menyusun pendapat, mengingat kembali hal-hal yang perlu disimak, dan memperjelas hal-hal yang masih meragukan. c) Kegiatan fasilitasi menolong subjek didik menerima suatu nilai, tetapi belum mengamalkan secara konsisten, meningkat dari pemahaman secara intelektual kekomitmen bertindak. d) Kegiatan fasilitasi menolong subjek didik berpikir lebih jauh tentang nilai yang dipelajari, menemukan wawasan sendiri, belajar dari teman-temannya yang telah menerima nilai. e) Kegiatan fasilitasi menyebabkan pendidik lebih dapat memahami pikiran dan perasaan subjek didik. f) Kegiatan fasilitasi memotivasi subjek didik menghubungkan persoalan nilai dengan kehidupan, kepercayaan, dan perasaan mereka sendiri.

4. Kecakapan untuk pengembangan nilainilai moral.

Kecakapan dalam mengembangkan nilai-nilai moral merupakan metode yang bersifat tidak langsung dengan cara memberikan kesempatan dan kecakapan kepada anak-anak muda untuk menjadi orang yang mandiri, konstruktif, pengambil keputusan yang efektif, dan menjadi warga negara yang baik. Keterampilan tersebut antara lain keterampilan menyimak, bertindak asertif, dan menemukan resolusi konflik secara ringkas.

\section{Evaluasi}

Evaluasi pendidikan karakter dilaksanakan untuk mengukur atau mengetahui apakah anak sudah memiliki satu atau sekelompok karakter yang diterapkan di sekolah. Tujuan evaluasi pendidikan karakter untuk mengetahui kemajuan hasil belajar dalam bentuk kepemilikan sejumlah indikator karakter tertentu pada anak dalam kurun waktu tertentu, serta mengetahui efektivitas proses pembelajaran yang dialami oleh anak.

Berdasarkan tujuan di atas bahwa evaluasi pendidikan karakter tidak terbatas pada pengalaman anak selama di kelas, tetapi juga pengelaman anak yang didapat di sekolah dan di rumah yang telah didesain sedemikian rupa oleh guru untuk mengembangkan moral anak. Evaluasi suatu moral anak tidak dapat dinilai dalam satu waktu saja, namun harus diobservasi dan diidentivikasi secara terus menerus dalam keseharian anak. Evaluasi pendidikan moral tidak hanya dilakukan oleh guru ketika di sekolah, namun dapat melibatkan pihak-pihak lain, di antaranya orang tua dan teman sebaya. 


\section{METODE}

Penelitian ini merupakan penelitian deskriptif dengan menggunakan pendekatan kualitatif. Subjek penelitian adalah anak-anak kelompok B TK PKK Sosrowijayan yang berlokasi di lokalisasi Pasar Kembang Yogyakarta. Data dikumpulkan melalui observasi, wawancara, dan dokumentasi. Observasi digunakan untuk mengamati langsung pendidikan moral yang diterapkan di TK PKK Sosrowijayan. Wawancara digunakan untuk menjaring data atau informasi yang berkaitan dengan perkembangan moral anak dari orang tua. Teknik pemeriksaan keabsahan data yang digunakan yaitu trianggulasi.

\section{HASIL DAN PEMBAHASAN}

Berdasarkan penelitian yang telah dilakukan diperoleh hasil bahwa pendidikan moral anak TK PKK Sosrowijayan dikembangkan secara formal di sekolah. Pendidikan moral dikembangkan secara terintegrasi dengan kegiatan harian anak. Pengembangan pendidikan moral anak di TK PKK Sosrowijayan Yogyakarta kurang optimal, karena pengembangan moral pada anak tidak memiliki ruang khusus dalam pengembangannya. TK PKK Sosrowijayan Yogyakarta lebih mengutamakan pengembangan intelektual anak. Hal ini terlihat dari adanya jam tambahan calistung (catat tulis hitung) untuk TK B selama satu jam setelah pembelajaran TK selesai. Tambahan jam dilakukan setelah sekolah selama 4 kali dalam seminggu, yakni setiap hari Senin sampai Kamis. Hasil wawancara juga menunjukkan bahwa alasan orang tua menyekolahkan anaknya di TK PKK Sosrowijayan Yogyakarta adalah bahwa lulusan TK PKK Sosrowijayan Yogyakarta sudah bisa calistung. Ketakutan orang tua tentang dampak negatif yang di timbulkan dari lingkungan disampingkan demi anaknya bisa calistung. Lingkungan lokalisasi memang tidak secara langsung memberikan dampak negatif kepada anak, karena anak-anak tidak langsung berinteraksi kepada psk. Anak-anak tidak diperbolehkan bermain di luar sekolah, namun kondisi di sekitar sekolah akan memberikan dampak negatif kepada anak. Anak memerlukan tempat yang mendukung demi perkembangannya, khususnya perkembangan moral. Meskipun tidak berinteraksi langsung, anak akan memperhatikan fenomena yang terjadi di sekitar sekolahnya. Anak akan memperhatikan beberapa fenomena ketika ia berangkat melewati gang sempit yang di situ tertulis tulisan yang tidak cocok untuk anak. Tulisan tersebut merupakan tulisan himbauan orang dewasa yang mengharuskan memakai kondom. Ada juga fenomena banyak orang yang tidur di depan halaman bahkan di jalan dikarenakan semalam habis mabuk-mabukan. Belum lagi ketika anak pulang sekolah terkadang ia melihat PSK yang sudah mangkal.

TK PKK Sosrowijayan Yogyakarta sudah mengupayakan untuk memberikan pengertian tentang fenomena tersebut. Menurut wawancara dengan guru pernah ada anak yang bertanya kalau ada orang yang tidur di jalan, tidak tidur di rumah. Guru menjawab bahwa orang tersebut mau pulang tetapi rumahnya jauh, karena sudah mengantuk sekali sehingga tidur dijalan. Memang tidak mudah memberikan pengertian kepada anak-anak tentang hal tersebut, namun setidaknya anak sudah mendapatkan jawaban dari fenomena yang ia lihat secara langsung. Pendidikan moral pada TK Sosrowijayan dikembangkan dengan pembiasaan. Pembiasaan dilakukan guru dengan tujuan untuk memberikan stimulasi kepada anak tentang nilai-nilai moral agar anak menjadi kegiatan yang rutin dikerjakan anak. Pengembangan moral anak juga dilakukan dengan TPA, namun kegiatan TPA tidak berlangsung secara rutin. Kegiatan TPA hanya mengajarkan anak membaca huruf hijaiyah, bukan untuk memberikan pengertian dan pemahaman pengenalan huruf hijaiyah. Kegiatan TPA juga seharusnya bisa dilaksanakan untuk mengembangkan aspek moral anak misalnya dengan bercerita tentang kehidupan yang nantinya di dalam cerita bisa disisipi nilai-nilai keagamaan dan kemanusiaan. Kegiatan TPA juga dilakukan tidak terjadwal. Kegiatan TPA dilakukan ketika anak-anak pulang sekolah dan membaca satu-persatu anak. Kegiatan TPA ditangani oleh satu guru, padahal jumlah anak 23 orang. Hal ini bisa dibayangkan dan menjadi kurang optimal dalam kegiatan TPA. Keteladanan juga diberikan sebagai metode untuk memberikan contoh yang baik kepada anak. Keteladanan ini terlihat dari perilaku guru yang santun kepada anak-anak. Perilaku tersebut adalah guru mengucapkan salam kepada anak ketika guru menyambut kedatangan anak. Pendidikan moral di TK PKK Sosrowijayan Yogyakarta 
dapat dilihat dari beberapa aspek untuk menunjang pendidikan moral anak, yaitu:

Materi TK PKK Sosrowijayan Yogyakarta.

Materi yang dikembangan di TK PKK

Sosrowijayan sesuai dengan Permendiknas No 58 Tahun 2009 tentang Standar Pendidikan Anak Usia Dini. Kajian dokumen kurikulum TK PKK Sosrowijayan Yogyakarta menunjukkan bahwa materi moral yang disampaikan sesuai dengan acuan pemerintah kurikulum KTSP. Materi yang disampaikan kepada anak TK PKK Sosrowijayan antara lain: Kecintaan kepada Tuhan YME, Rendah hati, Toleransi dan cinta damai, Peduli lingkungan, Hormat dan sopan santun, Kejujuran, Tanggung jawab, Tolong menolong, kerja sama dan gotong royong.

Pendidik TK PKK Sosrowijayan Yogyakarta.

Pendidik TK PKK Sosrowijayan Yogyakarta merupakan sosok yang ramah dengan anak, bahkan dengan orang tua juga terjalin interaksi seperti keluarga. Hal ini terlihat ketika adanya rencana kegiatan yang akan dilakukan TK, pengamatan peneliti menunjukkan adanya koordinasi ketika akan diadakan kunjungan ke museum untuk anakanak. Orang tua memberikan masukan kepada guru untuk menambah pengawasan kepada anak-anak. TK PKK Sosrowijayan mulai pembelajaran pukul 07.30. Guru TK PKK Sosrowijayan datang sebelum anak-anak datang ke sekolah. Guru selalu memastikan keadaan sekitar sekolahan steril dari kegiatan yang biasa terjadi dilokalisasi. Guru TK PKK Sosrowijayan Yogyakarta beragama Islam. Pakaian yang dikenakan guru juga menutup aurat dan dapat menjadi contoh untuk anakanak. Guru menjalin komunikasi yang baik dengan orang tua, hal ini terbukti ketika guru akan mengadakan sosialisasi tentang outbound guru tidak menggunakan undangan. Guru hanya berpesan kepada anak untuk besok ketika diantar orang tua langsung diajak duduk bareng anak-anak. kegiatan sosialisasi atau rapat dengan orang tua selalu diadakan pada pagi hari, mengingat pada siang hari orang tua banyak yang bekerja. Guru TK PKK Sosrowijayan menggunakan metode modeling dalam mengembangkan moral anak. Sesuai pernyataan yang diungkapkan oleh bu Yati pada tanggal 3 desember 2015 sebagai berikut: "kalau saya mencontohkan secara langsung, misalnya ketika datang, saya mengucapkan salam dan bersalaman dengan anak-anak. Hal itu dapat memberikan contoh kepada anak secara tidak langsung. Anak tidak sadar bahwa ia telah mengamatinya anak akan mengikuti dengan sendirinya". Dalam pengembangan moral, guru juga menerapkan punishment dan reward. Punishment berlaku kepada anak yang tidak menikuti aturan misalnya, ketika anak makan dan membuang sampah sembarangan. Anak yang membuang sampah sembarangan langsung disuruh untuk mengambil dan membuang sampah pada tempatnya. Reward akan berlaku kepada semua anak ketika selama satu hari mengikuti aturan yang telah disepakati. Reward yang diberikan berupa pujian dan motivasi kepada anak. Guru merupakan sosok yang sering diikuti anakanak, jadi guru harus bisa menjadi model yang baik yang dapat diikuti anak-anak.

Metode TK PKK Sosrowijayan Yogyakarta.

Metode pembelajaran yang digunakan dalam menerapkan pendidikan moral di TK PKK Sosrowijayan menggunakan beberapa metode pembiasaan, keteladanan, bercerita, dan menyanyi.

1. Pembiasaan

Pembiasaan yang dilakukan di TK PKK Sosrowijayan biasanya dilakukan pada kegiatan pembukaan. Pembiasaan tersebut berupa berdoa sebelum melakukan kegiatan belajar mengajar. Guru juga membisakan kepada anak untuk mengucapkan salam dan berjabat tangan dengan guru ketika datang dan pulang sekolah. Setiap pagi sebelum memulai kegiatan guru selalu menanyakan kepada anakanak siap yang berpamitan kepada orang tua. Metode pembiasaan juga dilakukan ketika anak-anak makan bekal yang dibawa dari rumah. Pembiasaan tersebut berupa berdoa sebelum makan dan saling berbagi kepada teman. Setiap makan bekal guru juga membawa bekal dan ikut makan. Selain itu guru juga bertujuan untuk mengajarkan berbagi kepada anak. Pengematan yang dilakukan peneliti menemukan bahwa guru membawa buah mangga, guru mengupas dan membagikan kepada anak-anak.

\section{Keteladanan}

Perilaku yang dilakukan guru akan diikuti oleh anak-anak. Jadi, guru harus dapat memberikan contoh yang baik untuk anakanak. Jadi guru TK PKK Sosrowijayan 
membiasakan menanamkan nilai-nilai moral dengan perilaku baik setiap harinya. Pihak sekolah juga mengadakan kerja sama degan orangtua dalam penanaman moral anak. Kerja sama penting dibangun untuk menyatukan persepsi antara kegiatan yang dilakukan di sekolah dengan di rumah. Anak akan bingung ketika apa yang dipahami di sekolah berbeda dengan apa yang dilakukan di rumah. Dalam hal ini guru dan orang tua memang harus sering berkomunikasi saling mendukung untuk perkembangan anak sehingga dapat berkembang dengan optimal.

3. Bercerita

$$
\text { Menurut kajian dokumen yang }
$$

dilakukan peneliti bahwa TK PKK Sosrowijayan Yogyakarta menggunakan metode bercerita untuk mengembangkan moral anak. Hasil pengamatan pada hari senin tanggal 16 november 2015. Pada hari itu pembelajaran TK PKK Sosrowijayan bertema tanaman dengan subtema cara berkembang biak tanaman. Kegiatan diawali dengan berdoa bersama-sama. Setelah berdoa guru bercerita dengan judul tesesat dihutan. Cerita tersebut berisi ada seekor anak itik yang terpisah dengan sang induk ketika mencari makan. Anak itik tersebut tersesat sendirian di hutan. Anak itik minta berteriak tolong, setelah lama tidak ada yang membantu anak itik tersebut menangis. Setelah berselang lama menangis, ada seekor kucing menghampiri anak itik tersebut. Anak itik pun takut, karena ia takut dimakan. Anak itik pun berlari, dan kucing mengejarnya. "itik tunggu, aku tidak memakan mu, aku mau membantumu". Anak itik pun berhenti dan bertanya pada kucing "apa benar kamu membantuku" kata sang anak itik. Iya kata kucing, kamu pasti mencari ibumu ya, kata kucing. Iya kamu tau dari mana, kata itik. Aku tadi bertemu dengan ibu ayam, dia kebingungan mencari anaknya. Ayo sekarang ikut aku, aku tuntukkan jalan menuju ibu kamu tadi. Anak itik pun mengikutinya, dan bertemu dengan ibunya. Anak itik pun senang sekali, dan berterima kasih dengan kucing tersebut. Cerita tersebut bertujuan untuk menanamkan moral anak agar saling tolong menolong kepada sesama. Setelah guru bercerita, guru bertanya kepada anak-anak tentang isi cerita tersebut dan anak menjawabnya. Metode bercerita memang efektif untuk mengembangkan moral anak, karena dalam cerita anak-anak dapat berimaginasi. Pada waktu anak berimaginasi kita dapat memasukkan nilai-nilai moral sehingga apa yang kita sampaikan dapat dipahami anak.

4. Bernyanyi

Pada program mingguan metode bernyanyi untuk mengembangkan kecintaan terhadap Tuhan Yang Maha Esa. Menyanyi lagu-lagu keagamaan dinilai dapat menanamkan nilai moral pada anak. Melalui bernyanyi guru bisa memodifikasi nyanyian sesuai dengan indikator yang akan dikembangkan, bahkan dapat dimodifikasi sesuai dengan tema.

\section{Evaluasi TK PKK Sosrowijayan Yogyakarta}

Evaluasi yang dilakukan guru dalam mengetahui perkembangan moral anak dengan menggunakan observasi. Observasi ini dilakukan setiap hari untuk mengetahui perkembangan moral anak. Evaluasi juga melibatkan orang tua, karena dalam evaluasi moral tidak bisa dilihat dari perilaku anak yang ditunjukkan selama di sekolah. Guru sering pesan kepada orang tua jika ada stimulus baru dari sekolahan, sehingga ketika di rumah orang tua dapat memberikan penguatan. Evaluasi di TK PKK Sosrowijayan melingkupi beberapa prinsip antara lain:

Evaluasi TK PKK Sosrowijayan Yogyakarta dilakukan guru secara berkelanjutan. Evaluasi dilakukan tidak hanya satu hari, namun dilakukan dengan pengamatan dari hari kehari. Hal ini terlihat ketika guru mengajar namun pandangan juga melihat ke seluruh siswa. Guru melihat seluruh siswa dan sesekali menegur siswa yang tidak memperhatikan dan melakukan tanya jawab kepada anak tentang yang dijelaskan guru.

Evaluasi TK PKK Sosrowijayan Yogyakarta dilakukan guru untuk seluruh aspek perkembangan anak, baik dari pengetahuan, sikap dan perilaku, maupun keterampilan anak. Hal ini terlihat dari $\mathrm{RKH}$ yang dibuat guru pada kolom penilaian guru memberikan skor berupa bulatan kosong sampai bintang. Bentuk itu merupakan kode untuk membuat skor anak sesuai kemampuan anak pada waktu itu. Bulatan kosong(o) berarti anak belum mampu/belum menguasai kegiatan yang diberikan guru. Tanda centang (v) berarti anak masih perlu bimbingan untuk melakukan kegiatan yang diberikan guru. Bulatan penuh berarti anak sudah mampu melakukan kegiatan yang diberikan guru. Bentuk bintang berarti 
anak sudah berkembang. Penilaian sikap dan perilaku guru menggunakan penilaian dengan mengamati anak secara langsung. Evaluasi TK PKK Sosrowijayan Yogyakarta dilakukan dengan melihat seluruh aktivitas yang dilakukan anak. penilaian dilakukan selama anak disekolah. Penilaian bahkan dilakukan ketika anak makan bersama dan bermaian. Penilaian anak TK PKK SosrowijayanYogyakarta dilakukan secara alami, jadi penilaian tidak ada. Penilaian dilakukan dengan mengamati kegiatan anak selama di sekolah. Guru TK PKK Sosrowijayan Yogyakarta melakukan penilaian dengan alami, sehingga anak-anak tidak merasa diperhatikan, yakni ketika mereka bermaian. Guru sesekali menegur anak dan memberikan nasihat ketika hal yang dilakukan membahayakan bagi anak. misalnya ketika anak mencuci tangan setelah memakan bekalnya dengan tidak tertib dan berebut antrian. Guru langsung menegur anak untuk antri dan menghemat air, karena kamar mandi menjadi satu dengan ruangan kelas B. Jika anak-anak tidak antri, air biasa membasahi ruangan kelas.

Evaluasi TK PKK Sosrowijayan Yogyakarta lebih mementingkan hasil dari pada proses anak. Hal ini terlihat ketika guru melakukan demonstrasi melipat kertas origami dengan membuat bunga. Guru tidak sabar dan segera membantu melipatkan kertas anak yang tidak bisa. Ketika berlatih menggunting, guru juga mengguntingkan hasil karya anak. Guru tidak memberikan kesempatan kepada anak untuk melakukannya sendiri meskipun hal ini berbahaya namun anak-anak biasa diberikan pemahaman tentang cera menggunting dan bahaya menggunting. Evaluasi tersebut juga terlihat adanya jam tambahan kepada anakanak kelas B tentang belajar calistung. Guru mempunyai target ketika anak-anak lulus harus bisa membaca, menulis, dan berhitung. Hal ini membuktikan bahwa TK PKK Sosrowijayan Yogyakarta lebih mementingkan hasil dari pada proses belajar anak.

\section{PENUTUP}

Berdasarkan hasil penelitian maka dapat disimpulkan sebagai berikut.

TK PKK Sosrowijayan dalam mengembangkan pendidikan moral untuk anak usia dini telah berjalan dengan baik, dari sisi materi, metode, dan evaluasi. Walaupun demikian, guru-guru lebih mementingkan hasil daripada proses belajar. Berkaitan dengan pengembangan moral yang dilakukan di sekolah, guru diharapkan menggunakan metode yang lebih bervariasi. Guru dalam melakukan evaluasi diharapkan menggunakan pedoman evaluasi dan lembar observasi sehingga guru dapat melakukan evaluasi secara objektif.

TK PKK Sosrowijayan Yogyakarta berada di lokasi yang kurang mendukung untuk perkembangan anak. Sebaiknya TK PKK Sosrowijayan pindah dari lokasi lokalisasi ke tempat yang lebih baik dan mendukung bagi perkembangan moral anak usia dini.

\section{UCAPAN TERIMA KASIH}

Akhirnya tulisan ini dapat terselesaikan dan dapat dimuat pada Jurnal Pendidikan Karakter edisi April 2017. Oleh karena itu, penulis memanjatkan puji dan syukur ke hadiran Allah Swt. Penulis juga mengucapkan terima kasih kepada seluruh anggota dewan redaksi JPK yang telah menerima tulisan ini kemudian melakukan penyuntingan sehingga dapat dimuat pada JPK edisi ini.

\section{DAFTAR PUSTAKA}

Ahmad. M. Nasih dan Lilik, N. Kholidah. 2009. Metode dan teknik pembelajaran pendidikan agama islam. Bandung: PT Rafika Aditama.

Darmiyati, Zuchdi. 2008. Humanisasi pendidikan: menemukan kembali pendidikan yang manusiawi. Jakarta: Bumi Aksara.

Fathul, Mu'in. 2011. Pendidikan karakter: kontruksi pada anak usia dini di Sekolah Raudhatul Athfal (RA) Habibillah. Jurnal Ilmiyah Widya. 2337-6686. Teoritik \& Paraktik: Jogjakarta: Ar-Ruzz Media.

Santrock, John, W. 2007. Perkembangan anak, ed ketujuh, jilid kedua. Erlangga: Jakarta.

2010. Child Development, eleventh edition. Mc.Graw Hill: Inc.

Kohlberg, Lawrence. 1995. Tahap-tahap perkembangan moral. Yogyakarta: Kanisius.

Maimunah, Hasan. 2012. Pendidikan anak usia dini. Diva Press: Bandung. 
Nurul, Zuriah. 2007. Pendidikan moral dan budi pekerti: dalam perspektif perubahan. Jakarta: Bumi Aksara.

Kostelnik, Marjorie. J, dkk. 1999. Developmentally appropriate curiculum. New Jersey: Prentice Hall. Poespoprodjo. 1998. Filsafat moral. Remaja Karya: Bandung. 